\title{
MEASURING THE PERCEPTION OF SAFETY AMONG TAIWAN CONSTRUCTION MANAGERS
}

\author{
Wei Tong Chen ${ }^{1}$, Chun Sheng $\mathrm{Lu}^{2}$, Shu-Shun Liu ${ }^{3}$, Min-Shun Wang ${ }^{4}$ \\ ${ }^{1,3}$ Department of Construction Engineering, National Yunlin University of Science \& Technology, \\ 123, Section 3, University Road, Touliu 64002, Taiwan \\ ${ }^{2}$ Graduate School of Engineering Science \& Technology at National Yunlin University \\ of Science \& Technology, 123, Section 3, University Road, Touliu 64002, Taiwan \\ ${ }^{4}$ Department of Property Management, Kainan University, No. 1, Kainan Road, Luzhu Shiang 33857, Taiwan \\ E-mails: ${ }^{1}$ chenwt@yuntech.edu.tw (corresponding author); ${ }^{2}$ lu9116213@yahoo.com.tw; \\ ${ }^{3}$ ssliu@yuntech.edu.tw; ${ }^{4}$ wangmss.wangmss@msa.hinet.net
}

Received 28 Feb. 2011; accepted 09 Apr. 2011

\begin{abstract}
Using Statistical Package for the Social Science (SPSS) and Structural Equation Modeling (SEM), this study develops a model to evaluate construction managers' perception of safety as relates to six aspects: human error (HE), safety resource and application (SRA), safety equipment and training (SET), site culture and external factors (SCF), safety inspection and audit (SIA), and accident medium and activities (AMA). The model was used to identify and compare the level of safety perceived by Taiwanese construction managers including safety managers, contractor managers, public works managers, design and audit managers, owner audit and control managers, and others. Analysis reveals that safety managers have the highest perception of safety while owner audit and control managers have the lowest. Surprisingly, public works managers and design and audit managers have lower levels of perceived safety than do contractor managers. Apparently, reinforcing the perception of safety between these two types of construction personnel is important to reducing construction accidents in Taiwan.
\end{abstract}

Keywords: construction safety perception, construction manager, construction industry, construction accidents.

\section{Introduction}

According to Taiwan's Labor Safety and Health Law, a fatal occupational accident (FOA) is defined as an accident involving: (1) a death or (2) the injury of at least three workers resulting in one or more lost workdays. The FOA must be reported within 24 hours to the appropriate inspection agency. Between 1998 and 2007, Taiwan companies experienced an average of 350 FOAs annually. In particular, 180 construction accidents resulted in 182 deaths. The number of fatal construction accidents in Taiwan is only second to that of mining and quarrying industries (Council of Labor Affairs 2008). Although the rate of FOAs per 1,000 workers in the construction field has declined slightly in recent years, the number is still significantly higher than in developed countries including the UK, USA, and Japan (Table 1).

A jobholder's perception can significantly affect his/her behavioral intention. A more positive perception usually accompanies high behavioral intention and viceversa (Yu 2006). The safety perception of Taiwan's construction jobholders is restricted because Taiwan's construction occupational accident investigations mainly focus on the number of fatalities and injuries, accident type, accident medium, work trade, and location. The construction accident rate remains high because of the specific environmentand insufficient safety precautions in the industry. According to Wang et al. (2006), despite increased official and industrial emphasis on construction safety issues in recent years, construction accidents in Taiwan still largely result from jobholders' inadequate safety perception.

Table 1. Occupational fatalities in the construction industry of different countries

\begin{tabular}{cccccc}
\hline & \multicolumn{5}{c}{ Injury Rate of OFAs (Per 1,000 workers) } \\
\cline { 2 - 6 } year & Taiwan & $\begin{array}{c}\text { Hong } \\
\text { Kong }\end{array}$ & Japan & $\begin{array}{c}\text { United } \\
\text { Kingdom }\end{array}$ & U.S.A. \\
\hline 2000 & 0.223 & 0.364 & 0.124 & 0.064 & 0.130 \\
\hline 2001 & 0.210 & 0.349 & 0.120 & 0.053 & 0.130 \\
\hline 2002 & 0.188 & 0.328 & 0.120 & 0.051 & 0.122 \\
\hline 2003 & 0.175 & 0.390 & 0.120 & 0.044 & 0.117 \\
\hline 2004 & 0.131 & 0.268 & 0.120 & 0.049 & 0.119 \\
\hline 2005 & 0.172 & 0.422 & 0.120 & 0.037 & 0.110 \\
\hline 2006 & 0.161 & 0.303 & 0.110 & 0.038 & 0.108 \\
\hline 2007 & 0.122 & 0.379 & 0.130 & 0.034 & 0.105 \\
\hline mean & 0.174 & 0.350 & 0.121 & 0.046 & 0.118 \\
\hline Source: & Council & &
\end{tabular}

Source: Council of Labor Affairs (2008)

Note: Excludes traffic accidents

Construction jobholders' poor awareness of safety concepts and poor enforcement of safety regulations 
mean that the management of construction safety urgently needs to be strengthened thus verifying the safety perception of various construction jobholders would help towards better construction safety control. With a focus on construction jobholders, we explore the root causes of these issues, and develop a model using questionnaire surveys and statistical analysis.

\section{Previous studies}

\subsection{Construction accidents}

Construction accidents in Taiwan are usually classified into five categories: falls from elevation, electric shock, caught in/between, struck by, and others. Determining the possible causation factors of these accident types is difficult due to the breadth of the categories (Hinze et al. 2005). However, management is the most critical factor in the occurrence of construction accidents (Mohan, Zech 2005; Liao, Perng 2008). A number of other factors, such as accident trends, work trade, accident type, and differences between different countries (areas) correlated with occupational injuries in the construction industry and were collected for a review of relevant studies of occupational injuries in Taiwan. Table 2 summarizes 11 studies on construction accidents, and shows that the topics most discussed included root causes, type, and medium of accident, and that risk and safety level are secondary issues. However, investigation into construction accident causes is still inadequate Cheng et al. (2010) explore the cause-effect relationships of occupational accidents in Taiwan's construction industry. Several factors affect construction safety management, and the special characteristics of the construction industry, such as the increasing number of large-scale projects, poor on-site conditions, and the complexities of construction trade combinations, all affect safety management. Törner and Pousette (2009) identified four main categories of construction safety preconditions and components: (1) project characteristics and nature of the work; (2) organization and structures; (3) collective values, norms, and behaviors; (4) individual competence and attitudes. According to Smith et al. (2006), ladder falls can lead to fractures that have more serious consequences than other ladderrelated injuries. Mohan and Zech (2005) noted the high frequency of traffic-related accidents among construction workers working on roads. Idoro (2008) investigates the level of efforts made by Nigerian contractors to maintain a healthy and safe work environment. The research reveals that the management efforts made by Nigerian contractors to ensure a healthy and safe work environment are yet to have meaningful impact. It suggests increased efforts on local health and safety $(\mathrm{H} \& \mathrm{~S})$ regulations, structures for managing $H \& S$ in both head and site offices and provision of $\mathrm{H} \& \mathrm{~S}$ incentives as measures for improving safety in the Nigerian construction industry. Additionally, Giretti et al. (2009) even developed a new, advanced

Table 2. Construction industry accident issues

\begin{tabular}{|c|c|c|}
\hline Topic & References & Research contents \\
\hline \multirow[t]{2}{*}{$\begin{array}{l}\text { Falling } \\
\text { accidents }\end{array}$} & Bobick (2004) & $\begin{array}{l}\text { During 1992-2000, more than 50\% of all fall-related deaths occurred in the Construction Di- } \\
\text { vision whereas, during the same period, only } 11 \% \text { of fall-related fatalities occurred in the } \\
\text { Manufacturing and Agriculture, Forestry, and Fisheries Divisions combined. }\end{array}$ \\
\hline & Huang et al. (2000) & $\begin{array}{l}\text { Flaws in facility management, such as safety prevention, temperature, openings, scaffold and } \\
\text { ladder are the major causes of occupational fatalities and serious injuries. }\end{array}$ \\
\hline \multirow[t]{3}{*}{$\begin{array}{l}\text { Root causes } \\
\text { of accidents }\end{array}$} & Hinze et al. (1998) & $\begin{array}{l}\text { Injuries were clustered into } 20 \text { possible cause categories, rather than the traditional five } \\
\text { groups of falls, struck by, electric shock, caught in/between, and other. Additional or second- } \\
\text { ary cause codes were also developed. }\end{array}$ \\
\hline & $\begin{array}{l}\text { Arboleda and } \\
\text { Abraham (2004) }\end{array}$ & $\begin{array}{l}\text { In the year } 2000 \text {, the construction industry accounted for } 4.7 \% \text { of USA GDP and } 7 \% \text { of the } \\
\text { total workforce but } 19.5 \% \text { of all reported occupational fatalities. }\end{array}$ \\
\hline & $\begin{array}{l}\text { Lipscomb et al. } \\
(2010)\end{array}$ & $\begin{array}{l}\text { Contact injuries accounted for } 54 \% \text { of all construction-related ER visits, primarily for injuries } \\
\text { caused by contact with discharged nails from pneumatic nail guns, with hand held power } \\
\text { saws, and fixed saws. }\end{array}$ \\
\hline \multirow[t]{2}{*}{$\begin{array}{l}\text { Accident } \\
\text { statistics }\end{array}$} & Beavers et al. (2006) & $\begin{array}{l}\text { The study examined 1997-2003 Occupational Safety and Health Administration's (OSHA) } \\
\text { fatality investigations to determine proximal causes and contributing physical factors. }\end{array}$ \\
\hline & Cohen et al. (2006) & $\begin{array}{l}\text { Work-related fatalities between the years } 1998 \text { and } 2002 \text { are described by victim de- } \\
\text { mographics, types of incidents, victim occupations, and industries and locations in which they } \\
\text { worked. }\end{array}$ \\
\hline \multirow[t]{2}{*}{$\begin{array}{l}\text { Risk } \\
\text { planning }\end{array}$} & $\begin{array}{l}\text { Lee and Halpin } \\
\text { (2003) }\end{array}$ & $\begin{array}{l}\text { Construction accidents are associated with poor planning of operational tasks, insufficiently } \\
\text { established practices for dealing with accidents, and a lack of safety training and safety recog- } \\
\text { nition. The research identified that training, supervision, and preplanning are the most critical } \\
\text { factors related to construction accidents. }\end{array}$ \\
\hline & $\begin{array}{l}\text { Gangwar and } \\
\text { Goodrum }(2005)\end{array}$ & $\begin{array}{l}\text { According to the US Bureau of Labor Statstics' Census of Fatal Occupational Injuries, the } \\
\text { total number of fatalities in the US private construction sector in } 2003 \text { was } 1126 \text {, the equiva- } \\
\text { lent of } 11.7 \text { worker fatalities for every } 100,000 \text { construction workers. }\end{array}$ \\
\hline $\begin{array}{l}\text { Level of } \\
\text { safety }\end{array}$ & Fang et al. (2004) & $\begin{array}{l}\text { The research uses multifactor linear regression (MLA) to conclude that on-site safety man- } \\
\text { agement performance is closely related to organizational and economic factors, along with } \\
\text { factors related to the relationship between management and labor on site. }\end{array}$ \\
\hline $\begin{array}{l}\text { Safety } \\
\text { knowledge }\end{array}$ & Chua and Goh (2004) & $\begin{array}{l}\text { The US construction industry accounted for } 20 \% \text { of all occupational fatalities, but only } 5 \% \text { of } \\
\text { the US workforce. }\end{array}$ \\
\hline
\end{tabular}


system mainly devoted to automatic real-time health and safety management on construction sites. Their research focuses mainly on the development of a reliable methodology for real-time monitoring of the position of both workers and equipment in outdoor construction sites by applying Ultra Wide Band based technologies.

\subsection{Safety perception}

An individual's perception depends on different external environments, personal characteristics, and individual conditions. From the perspective of management, generalized perception includes consciousness and response at the initial stage. Griffin and Neal (2000) defined safety perception as "how workers view safety related policies, procedures and other workplace attributes concerned with safety". The most relevant perceptual indicators in this regard are formal and informal policies, procedures, and practices concerning focal organizational facets, such as service and safety (Zohar 2000). Safety perception is correlated with accident rates, quality of the safety climate, workers' working attitude, management and equipment, organizational culture and management support.

Safety climate and safety culture are mutually related but distinguishable. Safety culture expresses itself through the safety climate as features that can be discerned from workers' attitudes and perceptions (Guldenmund 2000). Safety culture refers to 'the attitudes, beliefs, and perceptions shared by natural groups as defining norms and values, which determine how they react in relation to risks and risk control systems' (Hale 2000). The usefulness of safety climate as a diagnostic tool ought to reside in its ability to identify detailed and precise challenges critical to safety improvement (Meliá et al. 2008).

It is comparatively difficult to evaluate construction jobholders' safety perception. The occupational safety climate in Taiwan is regarded as an organizing component employees' overall safety perception (Tsai et al. 2003), and self-safety behavior and perception combine to form one measurement that defines safety at work. Although Wu et al. (2010) investigated the safety culture of Taiwan telecommunications industry, and Kuo et al. (2006) explored the state of the organizational safety culture in Taiwan's construction industry, they did not focus on managers' safety perception, and studies related to construction safety perception are lacking in general.

\section{Data collection}

The aim of this study is to build a perception scale to measure construction jobholders' safety perception levels. The concept of safety perception here is derived from selections of indicators affecting construction safety, as well as perception indicators based on studies on construction safety. Fig. 1 shows the procedure and applied methods of the perception evaluation model. First, we interviewed various practitioners to verify extracted variables. Next, several questionnaires were distributed to construction jobholders and the results were analyzed using statistics software and exploratory factor analysis
(EFA). Finally, the model variables and path effect were developed to evaluate construction jobholders' safety perceptions.

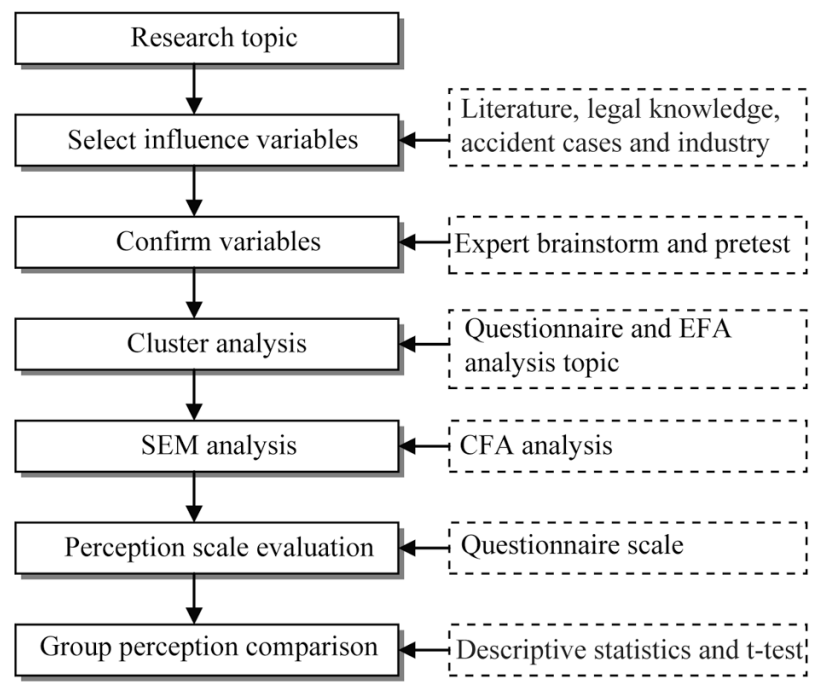

Fig. 1. Procedure and applied methods of perception analysis

The perception-related variables used here are taken from the occupational safety literature, including nine international and two local construction-related journals. We summarize 234 variables affecting construction safety perception by reviewing 34 articles published from 1997 to 2008 and referring to accidents in Taiwan's construction industry. Among these variables, 43 were selected and reviewed by 15 construction experts (5 public works experts, 2 engineering advisers company experts, 4 contractor experts, 2 labor safety experts, and 2 architects) equipped with at least 17 years experience in construction safety (Table 3 ). Based on the interview results, the list of variables was reduced to 36 , representing 36 questions of the questionnaire. Adopting a 7-point Likert scale in the questionnaire, the options were divided into different categories of importance from "very important" (7 points) to "very unimportant" (1 point).

According to Stevens (2002), the sample size used for factor analysis should be 2-20 times greater than the number of variables to be analyzed, and at least five observations for each variable are indispensable for the development of a reliable factor framework. The pretest questionnaire of this study was distributed to construction jobholders and 110 valid questionnaires (over three times the number of variables) were collected. Reliability analysis of the valid questionnaires indicated that Cronbach's $\alpha$ was 0.960 ; variable correlation was medium to high (0.423 0.728); variables were extracted between 0.543 and 0.781 via principal component analysis (with extracted values all greater than 0.5 ). All 36 variables were retained and incorporated into the formal questionnaire.

Construction jobholders generally include contractors, design consultants or architects, owner personnel, public works units, and laborer safety/research personnel. The study distributed 480 questionnaires to design and audit managers (e.g., architects and professional engineers, design and audit managers, and project managers), 
contractors (e.g., superintendents, safety managers, foremen, and supervisors), government officials and scholars (e.g., occupational safety officers, engineers, and engineering audit and control managers), and others (owners and engineers). Of the 387 returned questionnaires, 364 were valid (over 10 times the number of investigated variables). SPSS V15.0 was first used to carry out the exploratory factor analysis (EFA) and extract principal factors. Various statistical analyses, including the KaiserMeyer-Olkin (KMO) and Bartlett's Test, Communalities, Total Variance Explained, Screen Plot, Component Matrix, Rotated Component Matrix, and Component Transformation Matrix were conducted sequentially to delete some variables for better results. Table 4 displays the procedure of deleting variables and Table 5 shows the fifth stage analysis of the rotated cluster matrix.

\section{Model building and validation}

In this study, EFA was conducted with the variables of relevant factors and the initial analysis results for clusters of variables were then referred to confirmation factor analysis (CFA). According to Hair et al. (2006), SEM may be used for a variety of purposes, including both interdependence and dependence analyses. To either demonstrate path relationships or verify a scale's internal framework, SEM depends on exact variances and properties of one study to describe hypothetical relationships between variables and to realize verification statistically. The SEM model fit is evaluated in two stages: 1) validating the measurement model; and 2) validating the structural model. The firstorder SEM emphasizes the relationships between the structural models and variable loading analyses. The secondorder SEM emphasizes both the variable loading and path analysis of the framework. Referring to Fig. 2, we present a scale for construction jobholders' empirical safety perception and perform SEM analysis through Analysis of Moment Frameworks (AMOS) 7.0.

\subsection{Model building and correction}

Within the framework for the perception model and SEM principles for constructing a path diagram for SEM causal relationships of jobholders' perception, the path diagram can be transferred to the measurement model and the structural model of SEM, wherein variables and measurement errors to be estimated should be marked. In accordance with variables under each component, the rotated component matrix was used to analyze results and denominate them with six EFA aspects. With 364 valid samples, 26 observed variables, six endogenous latent variables $(\eta)$, and one exogenous latent variable $(\xi)$ (Table 6), the goodness-of-fit for the theoretical SEM model was examined stepwise.

Table 3. Description of initial variables

\begin{tabular}{lll}
\hline \multicolumn{1}{c}{ Classification } & \multicolumn{1}{c}{ Variables (No.) } & \multicolumn{1}{c}{ References } \\
\hline Human related & $\begin{array}{l}\text { Unfamiliarity with work, time shortage, new methods and technol- } \\
\text { ogies, defective equipment or inappropriate use, misjudgment, dis- } \\
\text { tractions, etc. (6) }\end{array}$ & $\begin{array}{l}\text { Huang and Hinze (2003); Wantanakorn } \\
\text { et al. (1999); Navon and Kolton (2006) }\end{array}$ \\
\hline $\begin{array}{l}\text { Performance } \\
\text { related }\end{array}$ & $\begin{array}{l}\text { Fatal accidents, injuries, time or resources lost due to injuries, ab- } \\
\text { senteeism, safety inspection and culture, and injuries requiring first } \\
\text { aid, etc. (5) }\end{array}$ & $\begin{array}{l}\text { Saurin } \text { et al. (2004); Cox et al. (2003); } \\
\text { Hinze and Godfrey (2003); Arboleda } \\
\text { and Abraham (2004) }\end{array}$ \\
\hline Accident related & $\begin{array}{l}\text { Unsafe site conditions, unsafe methods or sequencing, labor law } \\
\text { violations, external factors, company audit, lack of safety training, }\end{array}$ & $\begin{array}{l}\text { Beavers } \text { et al. (2006); Arboleda and } \\
\text { Abraham (2004); Navon and Kolton } \\
\text { (2006) }\end{array}$ \\
\hline Risk related & $\begin{array}{l}\text { Insufficient risk perception, project design factors, insufficient risk } \\
\text { assessment, insufficient training, inadequate safety culture and poli- } \\
\text { cies, and a lack of safety equipment or tools (6) }\end{array}$ & $\begin{array}{l}\text { Lee and Halpin (2003); Chua and Goh } \\
\text { (2004); Thevendran and Mawdesley } \\
\text { (2004); Navon and Kolton (2006) }\end{array}$ \\
\hline $\begin{array}{l}\text { Management } \\
\text { related }\end{array}$ & $\begin{array}{l}\text { Safety laws, safety investment, cooperation and communication, } \\
\text { safety education, subcontractor management, site safety environ- } \\
\text { ment, jobsite safety inspections, etc. (7) }\end{array}$ & $\begin{array}{l}\text { Gyi } \text { et al. (1999); Saurin } \text { et al. (2004); } \\
\text { Tam et al. (2003); Fang et al. (2004) }\end{array}$ \\
\hline Control related & $\begin{array}{l}\text { Site safety meetings, pre-tender risk assessment, punishment for } \\
\text { rule violations, renewed safety policies, emergency response sys- }\end{array}$ & $\begin{array}{l}\text { Huang and Hinze (2006); Wang } \text { et al. } \\
\text { (2006) }\end{array}$ \\
& $\begin{array}{l}\text { tem, and safety audits (6) } \\
\text { Rates of occupational fatalities, medium and category of accident, }\end{array}$ & $\begin{array}{l}\text { Huang and Hinze (2003); Hinze } \text { et al. } \\
\text { (2005); Beavers } \text { et al. (2006); Chi and } \\
\text { annual accident rate, related categories and activities, high risk ac- } \\
\text { tivities, and definition of severe accidents (6) }\end{array}$ \\
\hline
\end{tabular}

Table 4. Summary procedure of factor analysis for deleted variables

\begin{tabular}{ccccl}
\hline Stage & $\begin{array}{c}\text { Cronbach's } \\
\alpha\end{array}$ & $\begin{array}{c}\text { No. of variables } \\
\text { used }\end{array}$ & $\begin{array}{c}\text { No. of variables } \\
\text { deleted }\end{array}$ & \multicolumn{1}{c}{ Criteria of deleted variable } \\
\hline 1st & 0.923 & 36 & 2 & Difference of factor loading $<0.5$ (SC18, SC30) \\
\hline 2nd & 0.922 & 34 & 2 & Factor compose only two variables (SC2, SC3) \\
\hline 3rd & 0.926 & 32 & 4 & Difference of factor double loading $<0.3$ (SC8, SC12, SC22, SC29) \\
\hline 4th & 0.911 & 28 & 2 & Difference of factor double loading $<0.3$ (SC7, SC24) \\
\hline 5th & 0.901 & 26 & 0 & Factor loadings $>0.5 ;$ Difference of double loading $<0.3$ \\
\hline
\end{tabular}


Table 5. Rotated cluster matrix of the $5^{\text {th }}$ stage analysis

\begin{tabular}{|c|c|c|c|c|c|c|}
\hline $\begin{array}{l}\text { Vari- } \\
\text { able }\end{array}$ & $\begin{array}{c}\text { Cluster } \\
1\end{array}$ & $\begin{array}{c}\text { Cluster } \\
2\end{array}$ & $\begin{array}{c}\text { Cluster } \\
3\end{array}$ & $\begin{array}{c}\text { Cluster } \\
4\end{array}$ & $\begin{array}{c}\text { Cluster } \\
5\end{array}$ & $\begin{array}{c}\text { Cluster } \\
6\end{array}$ \\
\hline$\overline{\text { SC31 }}$ & 0.650 & & & & & \\
\hline SC32 & 0.719 & & & & & \\
\hline SC33 & 0.788 & & & & & \\
\hline $\mathrm{SC} 34$ & 0.702 & & & & & \\
\hline SC35 & 0.766 & & & & & \\
\hline SC36 & 0.818 & & & & & \\
\hline SC9 & & 0.651 & & & & \\
\hline SC10 & & 0.680 & & & & \\
\hline SC11 & & 0.665 & & & & \\
\hline $\mathrm{SC} 21$ & & 0.614 & & & & \\
\hline $\mathrm{SC} 23$ & & 0.527 & & & & \\
\hline $\mathrm{SC} 1$ & & & 0.753 & & & \\
\hline $\mathrm{SC} 4$ & & & 0.712 & & & \\
\hline SC5 & & & 0.649 & & & \\
\hline SC6 & & & 0.658 & & & \\
\hline SC16 & & & & 0.787 & & \\
\hline SC17 & & & & 0.756 & & \\
\hline SC19 & & & & 0.716 & & \\
\hline SC20 & & & & 0.805 & & \\
\hline SC13 & & & & & 0.708 & \\
\hline $\mathrm{SC} 14$ & & & & & 0.756 & \\
\hline $\mathrm{SC} 15$ & & & & & 0.641 & \\
\hline SC25 & & & & & & 0.708 \\
\hline SC26 & & & & & & 0.606 \\
\hline $\mathrm{SC} 27$ & & & & & & 0.715 \\
\hline SC28 & & & & & & 0.589 \\
\hline
\end{tabular}

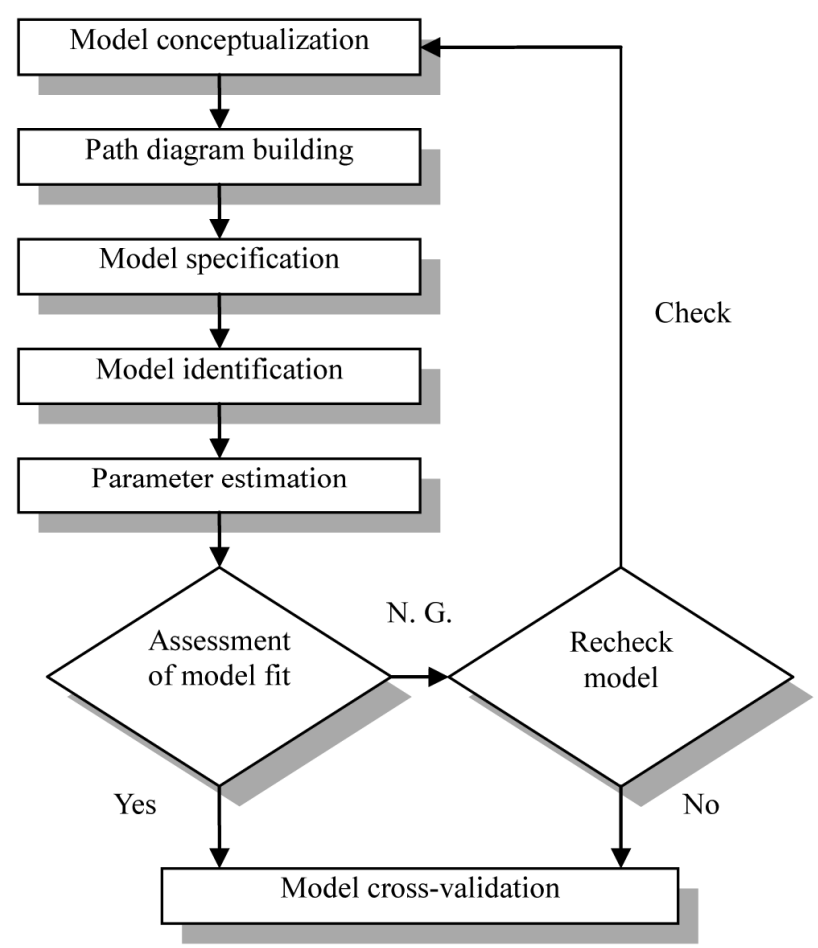

Fig. 2. Procedure of performing SEM analysis

Table 6. Variables of SEM analysis

\begin{tabular}{|c|c|}
\hline Observed variables & Endogenous and exogenous latent variables \\
\hline $\begin{array}{l}\text { SC1. Unfamiliarity with work (HE1) } \\
\text { SC4. Defective equipment or inappropriate use (HE2) } \\
\text { SC5. Misjudgment (HE31) } \\
\text { SC6. Distractions (HE4) } \\
\text { SC9. Safety inspection and culture (SRA1) } \\
\text { SC10. Injuries requiring first aid (SRA2) } \\
\text { SC11. Unsafe site conditions (SRA3) } \\
\text { SC21. Safety investments (SRA4) } \\
\text { SC23. Cooperation and communication (SRA5) } \\
\text { SC13. Lack of safety training (SET1) } \\
\text { SC14. Lack of safety equipment or tools (SET2) } \\
\text { SC15. Unsafe methods or sequencing (SET3) } \\
\text { SC16. Labor law violations (SCF1) } \\
\text { SC17. External factors (SCF2) } \\
\text { SC19. Psychology and education (SCF3) } \\
\text { SC20. Safety culture and policies (SCF4) } \\
\text { SC25. Jobsite safety inspections (SIA1) } \\
\text { SC26. Subcontractor management (SIA2) } \\
\text { SC27. Site safety environment (SIA3) } \\
\text { SC28. Safety audit (SIA4) } \\
\text { SC31. Punishment for rule violations (AMA1) } \\
\text { SC32. Medium and category of accidents (AMA2) } \\
\text { SC33. Annual accident rate (AMA3) } \\
\text { SC34. Related category and activities (AMA4) } \\
\text { SC35. High risk activities (AMA5) } \\
\text { SC36. Definition of severe accident (AMA6) }\end{array}$ & $\begin{array}{l}\eta 1 . \text { Human error (HE) } \\
\eta 2 . \text { Safety resource and application (SRA) } \\
\eta 3 . \text { Safety equipment and training (SET) } \\
\eta 4 . \text { Site culture and external factors (SCF) } \\
\eta 5 . \text { Safety inspection and audit (SIA) } \\
\eta 6 . \text { Accident medium and activities (AMA) } \\
\xi 1 . \text { Safety perception (SP) }\end{array}$ \\
\hline
\end{tabular}


Table 7. Goodness-of-fit measurement of the CFA model

\begin{tabular}{|c|c|c|c|c|c|}
\hline Evaluation indexes & $\begin{array}{l}\text { Suggested } \\
\text { value }\end{array}$ & $\begin{array}{c}\text { First-order } \\
\text { corrected model }\end{array}$ & $\begin{array}{l}\text { Second-order } \\
\text { original model }\end{array}$ & $\begin{array}{l}\text { Second-order fourth } \\
\text { corrected (Final) model }\end{array}$ & $\begin{array}{l}\text { Comments on } \\
\text { final model }\end{array}$ \\
\hline \multicolumn{6}{|l|}{ 1. Absolute fit indexes } \\
\hline $\operatorname{CMIN}\left(\chi^{2}\right)$ & The least & 628.398 & 647.298 & 485.777 & OK \\
\hline Degree of Freedom (D. F. ) & Without & 284 & 293 & 284 & $\mathrm{OK}$ \\
\hline P-value & $>0.05^{*}$ & 0.000 & 0.000 & 0.000 & $\mathrm{~N}>200$, ignored \\
\hline RMR & $<0.05$ & 0.026 & 0.027 & 0.024 & $\mathrm{OK}$ \\
\hline RMSEA & $<0.05$ & 0.058 & 0.058 & 0.044 & $\mathrm{OK}$ \\
\hline GFI & $>0.9$ & 0.886 & 0.883 & 0.911 & $\mathrm{OK}$ \\
\hline \multicolumn{6}{|l|}{ 2. Relative fit indexes } \\
\hline NFI & $>0.9$ & 0.848 & 0.844 & 0.883 & $>0.8$, accepted \\
\hline IFI & $>0.9$ & 0.911 & 0.908 & 0.948 & $\mathrm{OK}$ \\
\hline CFI & $>0.9$ & 0.910 & 0.907 & 0.947 & OK \\
\hline \multicolumn{6}{|l|}{ 3. Parsimonious fit indexes } \\
\hline $\operatorname{NCI}\left(\chi^{2} /\right.$ D. F. $)$ & $<2$ & 2.213 & 2.209 & 1.710 & OK \\
\hline PNFI & $>0.5$ & 0.741 & 0.761 & 0.771 & OK \\
\hline PCFI & $>0.5$ & 0.795 & 0.818 & 0.828 & OK \\
\hline Hoelter's Critical N & $\geq 200$ & 188 & 188 & 243 & OK \\
\hline \multicolumn{6}{|l|}{ 4. Cross-validation } \\
\hline AIC & The least & 762.398 & 763.298 & 619.777 & OK \\
\hline ECVI & The least & 2.100 & 2.103 & 1.707 & $\mathrm{OK}$ \\
\hline Conclusions & & $\begin{array}{l}\text { Goodness-of-fit N. } \\
\text { G. and partial corre- } \\
\text { lation coefficient } \\
>0.7\end{array}$ & $\begin{array}{l}\text { Goodness-of-fit } \\
\text { N. G. }\end{array}$ & Goodness-of-fit Indexes $r$ & ay be accepted. \\
\hline
\end{tabular}

Note: Suggested value could be ignored if the number of returned questionnaires exceed the number of questions by more than ten times (Stevens 2002)

Applying a model including 26 observed variables and 6 endogenous latent variables to the first-order correlated SEM, we obtained the various indices shown in Table 7. The values of root mean square error of approximation (RMSEA), goodness-of-fit index (GFI), normal fit index (NFI), normed chi-square index (NCI), and Hoelter's Critical $\mathrm{N}$ do not match the suggested values, and the correlation coefficients of some endogenous latent variables (e.g., HE, SRA, SET, SCF, SIA, and AMA) exceeded 0.7. Some higher-order common factors might exist within these latent variables.

The model with 26 observed variables, six endogenous latent variables, and one exogenous latent variable was used for the second-order original SEM. As seen from Table 7, the values of the abovementioned indices did not improve to pass their respective thresholds, thus the model required further correction. After two rounds of correction, most indices of the model approached the suggested values. With the variable-observed correlations added into the second-order model, the results generated by AMOS improved. The model is considered qualified in terms of GFI (Table 7). The path estimate coefficients are shown in Fig. 3.

The goodness-of-fit values from SEM statistical analyses and requirements recommended for the constructed model indicated a poor goodness-of-fit in the firstorder original SEM. The first-order correlated SEM gradually caused some goodness-of-fit indicators to match the suggested requirements for constructing a new model for comparison with the original model. Nevertheless, we incorporated the second-order model in the analyses because incorporating the converged first-order SEM results into the required conditions would cause the model to be very complicated and some factors' correlation coefficients to be extremely high.

With several corrections applied to the second-order model, the GFI, IFI and CFI for the fourth corrected (final) model are all greater than 0.90, matching requirements for the statistical indicators, with the exception of NFI (Jöreskog, Sörbom 1998). The study's NFI $(=0.883)$ was slightly smaller than the suggested value (0.9). Additionally, some authors, such as Bagozzi and Yi (1988), have used a more liberal cutoff NFI value of 0.80 . Furthermore, the non-absolute normal values may determine the observation variables and the modeling goodness-of-fit, meaning that PNFI is much more proper than NFI. As seen in Table 7, the PNFI of the proposed model is 0.771 , which is much greater than the suggested value $(0.5)$, indicating the acceptance of the developed model.

Although the acceptance of SEM is dependent on the overall index, the smaller the $\chi^{2}$, the more robust the SEM will be. There is no suggested value for degree of freedom (DF) which is related to NCI. Thus, the two indices cannot be considered independently (Jöreskog, Sörbom 1998; Kaplan 2000; Carmines, McIver 1981). After correcting the model, the cross-validation test for the final model indicated that the values of the Akaike information criterion (AIC) and the expected crossvalidation index (ECVI) were significantly reduced. As seen in Table 7, the ideal situation would be a smaller AIC and an ECVI value that corresponds to the requirement of Default $<$ Independence $<$ Saturated model. Thus, this study's safety perception model can be applied to empirical analyses. 


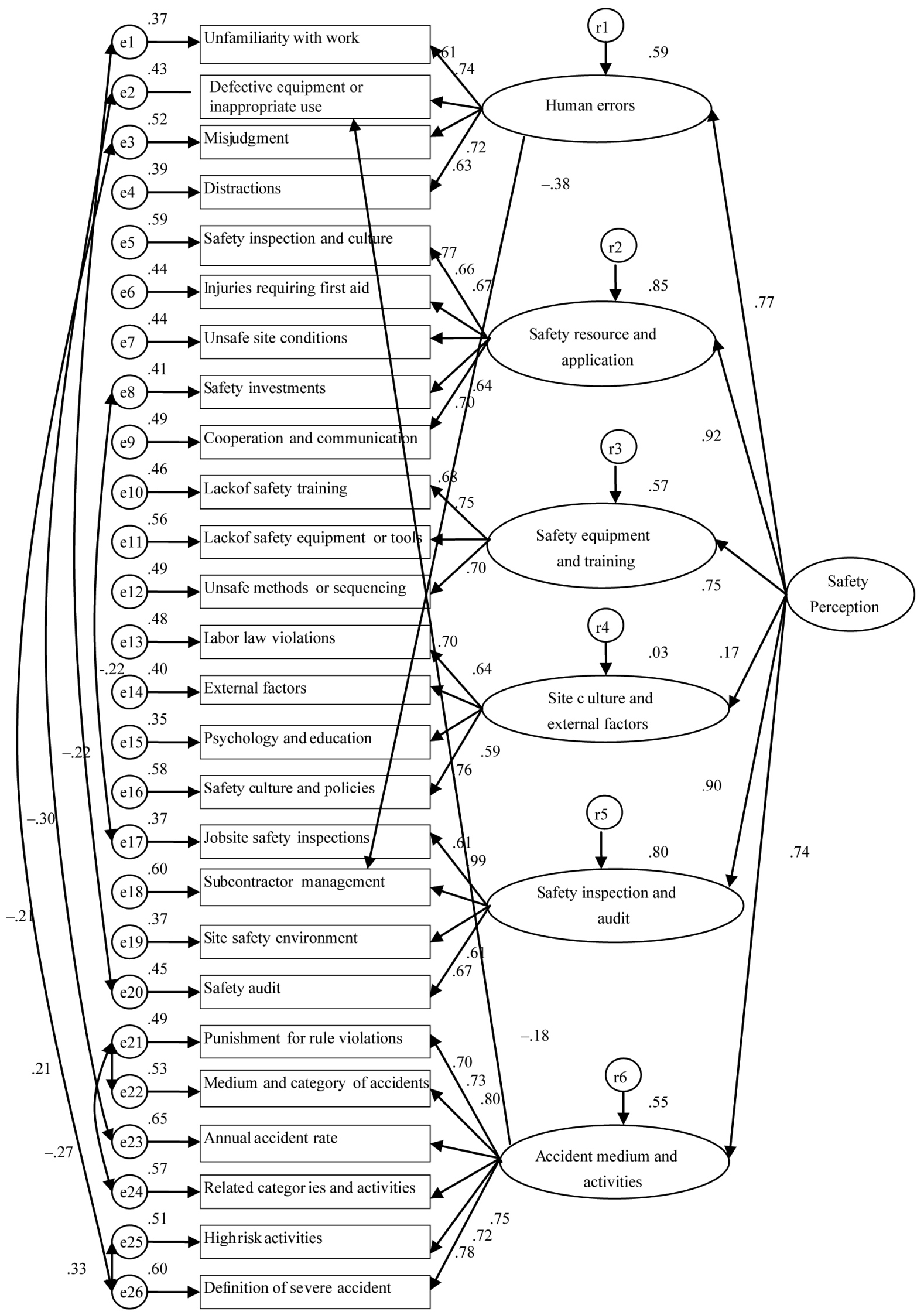

Fig. 3. Second-order fourth corrected (final) model 


\subsection{Model effects}

Direct, indirect and total effects can be used to interpret SEM. The direct effect is a structural coefficient indicating a relationship between two variables with a single straight line. The indirect effect is another structural coefficient indicating a relationship between two variables, but affected by another path rather than a direct straight line. The total effect is a combination of the direct and indirect effects. A path displays the directionaffecting setup of one model and interpretations can be reversely obtained along a path's arrow (Kaplan 2000).

From Fig. 3, the second-order model has six paths equipped with the direct effect. They are: human error $(0.770)$, safety resources and application (0.921), safety equipment and training (0.753), site culture and external factors (0.174), safety inspection and audit (0.896), and accident medium and activities (0.744). Paths of the firstorder model also have different direct effects, such as human error (4 paths), safety equipment and training (3 paths), safety resource and application (5 paths), safety inspection and audit (4 paths), site culture and external factors (4 paths), accident medium and activities (6 paths). Additionally, cross-loading path effects can be found in two paths including human error to subcontractor management (SIA2) and accident statistics to defective equipment or inappropriate use (HE2).

In this study, the direct effects of high-order latent variables on the six paths are indicated with their coefficients which are between 0.174 and 0.921 . Except for management action and risk with weakened effects causing a low perception path estimate coefficient, other latent variables have strong effects on the path estimate coefficient. The latent variables' effects on observed variables could be detected in 28 paths. A path's standardized coefficient should be between -0.377 and 0.987 . Except where cross loading occurs, most effect paths with coefficients between 0.5 and 0.95 indicate a good goodness-of-fit for the developed model (Hair et al. 2006).

\section{Safety perception analyzing}

Following the SEM model variables, we developed an evaluation table with 26 questions, which was then given to construction jobholders for the evaluation of safety perceptions. Groups were created and comparison analysis was performed based on the SEM model's path effects.

\subsection{Group perception comparison}

Through confirmatory SEM analysis, the Questionnaire Perception Estimate (QPE) was developed for each variable. Based on 26 variables selected by SEM, 26 questions were designed and five experts $(1$ construction safety, 1 design, 1 public works, and 2 contractors) verified the goodness-of-fit of these questions. The questionnaire was then distributed to 360 construction jobholders including safety managers, contractor managers, design and audit managers, public works managers, owner audit and control managers, and others. Of 253 returned questionnaires, 242 were valid (response rate 67.2\%). A 7point scale, in which 1 indicates "closest to the investi- gated fact" and 7 indicates "deviated far from the fact," was used to measure respondents' perception.

The procedure used to measure group perception was as follows: (1) computation of perception scores based on 242 valid questionnaires; (2) second-order fit model, derived from CFA, was incorporated into the analyses of all paths $\left(L_{i}\right)$; (3) the perception score $\left(W_{i}\right)$ from a corresponding question was multiplied by $\left(E_{i}\right)$; (4) cumulative results for all factors were multiplied by a high-order SEM path estimate coefficient for higher-order computations using this principle. With $E_{i}$ multiplied by $W_{i}$, the results were accumulated according to all paths for comparisons of six groups of jobholders' perceptions.

Table 8 shows how the perception scores are calculated. The order for all group scores (in descending order) is safety managers, contractor managers, public works managers, design and audit managers, owner audit and control managers, and others (Table 9). Significant differences were found between the perception of safety managers and that of the other five groups of jobholders. The average difference of 12.18 points $(76.35-64.17=$ 12.18 ) between safety managers and owner audit and control managers indicates a notable difference in safety perception among these groups of jobholder.

The benchmark confidence level for determining difference in perception is $95-99 \%$. Thus, there was a significant difference between safety managers and other groups and between contractor managers and owner audit and control managers or others, but not between contractor managers and design and audit managers or public works managers (Table 10). There was no significant difference between design and audit managers (who had perceptions similar to those of owner audit and control managers) and public works managers or others; between public works managers (who had perceptions similar to those of owner audit and control managers) and others; and there was no significant difference between owner audit and control managers and others.

\subsection{Results analysis}

Compared with the perception difference, safety managers have a much higher perception level than do the other five groups. The perception of contractor managers was similar to that of public works managers and design and audit managers. There was no significant difference observed between owner audit and control managers and others. The owner audit and control managers had the lowest perception level, because Taiwan's construction project owners heavily focus on schedules and costs but ignore safety (Wang et al. 2006).

We took the average perception of the safety managers as benchmark for construction jobholders' safety perception. In comparison, the contractor managers had a perception level of $92.1 \%$, while the other four groups had average perception levels ranging from $84 \%$ to $89.5 \%$. Despite not finding any jobholder group with a particularly low perception level, significant differences exist between some groups' safety perception levels, with a gap of 36.59 points $(=87.41 \sim 50.82)$ between the maximum and the minimum based on the QPE (Table 9). 
Table 8. Path effects and perception calculation example

\begin{tabular}{|c|c|c|c|c|}
\hline Second-order $\Sigma L_{i}\left(\Sigma\left(E_{i}^{*} W_{i}\right)\right)$ & First-order $(L i) \Sigma\left(E i^{*} W_{i}\right)$ & Variable & Estimate $\left(E_{i}\right)$ & Perception score $\left(W_{i}\right)$ \\
\hline \multirow{28}{*}{$\begin{array}{l}\text { Perception } \\
\Sigma=77.355\end{array}$} & \multirow{5}{*}{$\begin{array}{l}\text { Human error }(\mathrm{HE})\left(L_{i}=0.770\right) \\
\Sigma=14.072\end{array}$} & HE1 & 0.608 & 7 \\
\hline & & HE2 & 0.743 & 7 \\
\hline & & HE3 & 0.718 & 4 \\
\hline & & HE4 & 0.626 & 7 \\
\hline & & SIA2 & -0.377 & 7 \\
\hline & \multirow{5}{*}{$\begin{array}{l}\text { Safety resource and application } \\
\left(\text { SRA) }\left(L_{i}=0.921\right)\right. \\
\Sigma=19.324\end{array}$} & SRA1 & 0.771 & 5 \\
\hline & & SRA2 & 0.663 & 7 \\
\hline & & SRA3 & 0.666 & 7 \\
\hline & & SRA4 & 0.640 & 2 \\
\hline & & SRA5 & 0.698 & 7 \\
\hline & \multirow{3}{*}{$\begin{array}{l}\text { Safety equipment and training (SET) } \\
\left(L_{i}=0.753\right) \\
\Sigma=11.284\end{array}$} & SET1 & 0.679 & 7 \\
\hline & & SET2 & 0.747 & 5 \\
\hline & & SET3 & 0.699 & 4 \\
\hline & \multirow{4}{*}{$\begin{array}{l}\text { Site culture and external factors } \\
(\mathrm{SCF})\left(L_{i}=0.174\right) \\
\Sigma=12.697\end{array}$} & SCF1 & 0.696 & 1 \\
\hline & & SCF2 & 0.636 & 4 \\
\hline & & SCF3 & 0.591 & 7 \\
\hline & & SCF4 & 0.760 & 7 \\
\hline & \multirow{4}{*}{$\begin{array}{l}\text { Safety inspection and audit (SIA) } \\
\left(L_{i}=0.896\right) \\
\Sigma=20.076\end{array}$} & SIA1 & 0.607 & 7 \\
\hline & & SIA2 & 0.987 & 7 \\
\hline & & SIA3 & 0.606 & 7 \\
\hline & & SIA4 & 0.668 & 7 \\
\hline & \multirow{7}{*}{$\begin{array}{l}\text { Accident medium and activities } \\
\left(\text { AMA) }\left(L_{i}=0.744\right)\right. \\
\Sigma=26.919\end{array}$} & AMA1 & 0.700 & 7 \\
\hline & & AMA2 & 0.731 & 7 \\
\hline & & AMA3 & 0.804 & 4 \\
\hline & & AMA4 & 0.754 & 7 \\
\hline & & AMA5 & 0.716 & 7 \\
\hline & & AMA6 & 0.776 & 6 \\
\hline & & HE2 & -0.180 & 7 \\
\hline
\end{tabular}

Table 9. Questionnaire perception estimate of group ranking

\begin{tabular}{|c|c|c|c|c|c|c|c|}
\hline \multirow{2}{*}{ Groups } & \multirow{2}{*}{$\begin{array}{l}\text { Sample } \\
\text { no. }\end{array}$} & \multicolumn{3}{|c|}{ Perception estimate } & \multirow{2}{*}{ Std. } & \multirow{2}{*}{ Rank } & \multirow{2}{*}{$\begin{array}{l}\text { Ratio of individual } \\
\text { group to G1 (\%) }\end{array}$} \\
\hline & & Min. & Max. & Mean & & & \\
\hline G1. Safety managers & 28 & 61.19 & 87.41 & 76.35 & 6.37 & 1 & 100 \\
\hline G2. Contractor managers & 61 & 57.10 & 79.70 & 70.29 & 5.52 & 2 & 92.06 \\
\hline G3. Design and audit managers & 31 & 56.66 & 79.34 & 67.88 & 5.08 & 4 & 88.91 \\
\hline G4. Public works managers & 37 & 56.83 & 76.70 & 68.37 & 5.53 & 3 & 89.55 \\
\hline G5. Owner audit and control managers & 33 & 50.93 & 77.26 & 64.17 & 6.83 & 6 & 84.05 \\
\hline G6. Others & 52 & 50.82 & 76.42 & 66.62 & 5.11 & 5 & 86.99 \\
\hline All samples & 242 & 50.82 & 87.41 & 68.77 & 6.55 & & \\
\hline
\end{tabular}

Table 10. Significance of group t-test

\begin{tabular}{lcccccc}
\hline \multirow{2}{*}{ Groups t-test } & \multicolumn{5}{c}{ Significance $(p$ value; 2-tailed $) / 95 \%-99 \%$ confidence level } \\
\cline { 2 - 7 } & $\mathrm{G} 1$ & $\mathrm{G} 2$ & $\mathrm{G} 3$ & $\mathrm{G} 4$ & $\mathrm{G} 5$ & $\mathrm{G} 6$ \\
\hline G1. Safety managers & - & 0.000 & 0.000 & 0.000 & 0.000 & 0.000 \\
G2. Contractor managers & Difference & - & 0.044 & 0.089 & 0.000 & 0.000 \\
G3. Design and audit managers & Difference & Equal & - & 0.777 & 0.022 & 0.197 \\
G4. Public works managers & Difference & Equal & Equal & - & 0.009 & 0.056 \\
G5. Owner audit and control managers & Difference & Difference & Almost & Almost & - & 0.272 \\
G6. Others & Difference & Difference & Equal & Equal & Equal & - \\
\hline
\end{tabular}

Note: Equal- $p$ value $<0.005$; Almost- $p$ value $\geq 0.005$ or $<0.025$; Difference- $p$ value $\geq 0.025$ 
To implement safety protection and accident prevention in construction projects, the safety concept of some managers with low perception levels should be comprehensively reinforced to prevent a potentially catastrophic conditions gradually developing because of chronically poor construction safety. Safety perception is regarded a standard of construction safety performance and, in fact, most safety managers with labor safety certificates and safety-related training had higher average perception scores; however, design and audit managers with different specialties were found to have low average scores.

\subsection{Strategies for accident reduction}

The basic framework of strategies for construction accident reduction goes hand in hand with all levels of management. As indicated by the Construction Design and Management (CDM) regulations in the UK, owners, designers, and contractors have their own safety duties. However, most of Taiwan's construction owners rarely respect safety controls because they argue that contractors are fully responsible for safety (Zou 2008).

One of the root causes of problems related to Taiwan's construction safety is the incomplete implementation of a construction supervision system. Architects' failure to reach a consistent consensus on the supervision of construction safety has resulted in insufficient supervision of construction safety. Although related guidelines explicitly regulate the construction safety duties of contractors and supervisors in public works, the relevant statutes for most projects need to be revised to raise the effectiveness of the project supervision system.

Although cost, schedule, and quality are the main indicators of construction projects (McKim et al. 2000), the safety dimension should be added as one of these standards. As someone with a crucial role in the construction project, the owner dominates the setup of a safe environment to ensure construction safety. The owner should require the contractor to draw up a construction plan and a construction safety evaluation report, analyzing dangers occurring in various stages or operations, evaluating potential risks in operation environments and equipment, and developing construction safety criteria and precautions prior to the commencement of the project. The responsibilities of subcontractors include analyzing construction safety, regulating labor to comply with safety rules at construction sites, and thoroughly monitoring workers to ensure complete safety inspections prior to the commencement of the project.

\section{Conclusions and recommendations}

This study explores the safety perception of Taiwan's construction jobholders, using SPSS and SEM to develop an evaluation model for their safety perception. The developed model was then used to identify and compare the safety perception levels of Taiwanese construction jobholders. The developed model includes six aspects (HE, SRA, SET, SCF, SIA, and AMA). Six groups of jobholders were investigated including safety managers, contrac- tor managers, public works managers, design and audit managers, owner audit and control managers, and others.

Compared to other groups of Taiwan's construction jobholders, safety managers have the highest safety perception level while owner audit and control managers have the lowest. The safety perception levels of design and audit managers and public works managers were surprisingly low. In particular, design and audit managers play key roles in determining the contents of construction projects. As construction industry professionals, their safety perceptions could be expected to be no worse than those of any other construction professionals, but this is not the case. Public works managers are certified by government authority, and are supposed to not only have a high-level safety-related knowledge, but also consistently emphasize construction safety in all projects. Obviously, this is not the case in Taiwan's construction industry.

Implementation of required health and safety practices and effective training is important to reducing construction accidents (Cheng et al. 2010). Comprehensive implementation of construction safety measures and participation by jobholders in management and control are a critical part of a fundamental solution. In particular, construction managers are responsible for enhancing overall construction safety levels by improving safety perception through better practices and safety training. Additionally, reinforcing the safety perception of design and audit managers and public works managers is an urgent task. The framework proposed here can be upgraded and we suggest the computation of the relative coefficients for all aspects with paired comparisons be applied to these aspects for further comparison with recalculated scores for all groups' perceptions. Additionally, for assessing construction jobholders' safety perception levels, the sample size should expanded.

\section{Acknowledgements}

The authors would like to thank all survey participants. Special thanks also go to referees for their valuable comments on the paper.

\section{References}

Arboleda, C. A.; Abraham, D. M. 2004. Fatalities in trenching operations-Analysis using of accident causation models, Journal of Construction Engineering and Management 130(2): 273-280. http://dx.doi.org/10.1061/(ASCE)07339364(2004)130:2(273)

Bagozzi, R. P.; Yi, Y. 1988. On the evaluation of structural equation models, Journal of the Academy of Marketing Science 16(1): 74-94. http://dx.doi.org/10.1007/BF02723327

Beavers, J. E.; Moore, J. R.; Rinehart, R.; Schriver, W. R. 2006. Crane-related fatalities in construction industry, Journal of Construction Engineering and Management 132(9): 901-910. http://dx.doi.org/10.1061/(ASCE)0733-9364 (2006)132:9(901)

Bobick, T. G. 2004. Falls through roof and floor openings and surfaces including skylights: 1992-2000, Journal of Construction Engineering and Management 130(6): 895907. http://dx.doi.org/10.1061/(ASCE)0733-9364(2004) 130:6(895) 
Carmines, E. G.; McIver, J. P. 1981. Analyzing models with unobserved variables: analysis of covariance structures, in Bohrnstedt, G. W.; Borgatta, E. F. (Eds.). Social Measurement: Current Issues. Beverly Hills, CA: Sage Publications, 65-115.

Cheng, C.-W.; Lin, C.-C.; Leu, S.-S. 2010. Use of association rules to explore cause-effect relationships in occupational accidents in the Taiwan construction industry, Safety Science 48(4): 436-444.

http://dx.doi.org/10.1016/j.ssci.2009.12.005

Chi, C.-F.; Wu, M.-L. 1997. Effects of age and occupation on occupational fatality rates, Safety Science 27(1): 1-17. http://dx.doi.org/10.1016/S0925-7535(97)00046-5

Chua, D. K. H.; Goh, Y. M. 2004. Incident causation model for improving feedback of safety knowledge, Journal of Construction Engineering and Management 130(4): 542551. http://dx.doi.org/10.1061/(ASCE)0733-9364(2004) 130: 4(542)

Cohen, M. A.; Clark, R. E.; Silverstein, B.; Sjostrom, T.; Spielholz, P. 2006. Work-related deaths in Washington State, 1998-2002, Journal of Safety Research 37(3): 307-319. http://dx.doi.org/10.1016/j.jsr.2006.02.007

Council of Labor Affairs 2008.03.06. [Online], [cited 10 January 2011]. Available from Internet: http://www.cla.gov.tw/cgi-bin/SM_theme

Cox, R. F.; Issa, R. R. A.; Ahrens, D. 2003. Management's perception of key performance indicators for construction, Journal of Construction Engineering and Management 129(2): 142-151. http://dx.doi.org/10.1061/(ASCE)07339364(2003)129:2(142)

Fang, D. P.; Huang, X. Y.; Hinze, J. 2004. Benchmarking studies on construction safety management in China, Journal of Construction Engineering and Management 130(3): 424-432. http://dx.doi.org/10.1061/(ASCE)0733-9364 (2004)130:3(424)

Gangwar, M. G.; Goodrum, P. M. 2005. The effect of time on safety incentive programs in the US construction industry, Construction Management and Economics 23(8): 851859. http://dx.doi.org/10.1080/01446190500184527

Giretti, A.; Carbonari, A.; Naticchia, B.; De Grassi, M. 2009. Design and first development of an automated real-time safety management system for construction sites, Journal of Civil Engineering and Management 15(4): 325-336. http://dx.doi.org/10.3846/1392-3730.2009.15.325-336

Griffin, M. A.; Neal, A. 2000. Perceptions of safety at work: a framework for linking safety climate to safety performance, knowledge, and motivation, Journal of Occupational Health Psychology 5(3): 347-358.

http://dx.doi.org/10.1037//1076-8998.5.3.347

Guldenmund, F. W. 2000. The nature of safety culture: a review of theory and research, Safety Science 34(1-3): 215-257. http://dx.doi.org/10.1016/S0925-7535(00)00014-X

Gyi, D. E.; Gibb, A. G. F.; Haslam, R. A. 1999. The quality of accident and health data in the construction industry: interviews with senior managers, Construction Management and Economics 17(2): 197-204.

http://dx.doi.org/10.1080/014461999371691

Hair, J. F.; Black, B; Babin, B.; Anderson, R. E.; Tatham, R. L. 2006. Multivariate data analysis. $6^{\text {th }}$ ed. New York, NY: Macmillan. $928 \mathrm{p}$.

Hale, A. R. 2000. Culture's confusions, Safety Science 34(1-3): 1-14. http://dx.doi.org/10.1016/S0925-7535(00)00003-5
Hinze, J.; Godfrey, R. 2003. An evaluation of safety performance measures for construction projects, Journal of Construction Research 4(1): 5-15.

http://dx.doi.org/10.1142/S160994510300025X

Hinze, J.; Huang, X.; Terry, L. 2005. The nature of struck-by accidents, Journal of Construction Engineering and Management 131(2): 262-268. http://dx.doi.org/10.1061/ (ASCE)0733-9364(2005)131:2(262)

Hinze, J.; Pedersen, C.; Fredley, J. 1998. Identifying root causes of construction injuries, Journal of Construction Engineering and Management 124(1): 67-71. http://dx.doi.org/10. 1061/(ASCE)0733-9364(1998)124:1(67)

Huang, C. C.; Shiau, J. S.; Tung, C. Y.; Liou, Y. W. 2000. A study of the influential factors of labors' falling accidents, Journal of Occupational Safety and Health 8(4): 423-440 (in Chinese).

Huang, X.; Hinze, J. 2003. Analysis of construction worker fall accidents, Journal of Construction Engineering and Management 129(3): 262-271. http://dx.doi.org/10.1061/ (ASCE)0733-9364(2003)129:3(262)

Huang, X.; Hinze, J. 2006. Owner's role in construction safety, Journal of Construction Engineering and Management 132(2): 164-173. http://dx.doi.org/10.1061/(ASCE)07339364(2006)132:2(164)

Idoro, G. I. 2008. Health and safety management efforts as correlates of performance in the Nigerian construction industry, Journal of Civil Engineering and Management 14(4): 277-285. http://dx.doi.org/10.3846/1392-3730.2008.14.27

Jöreskog, K. G.; Sörbom, D. 1998. LISREL 8: structural equation modeling with the SIMPLIS command language. Chicago, IL: Scientific Software International, Inc. 226 p.

Kaplan, D. W. 2000. Structural equation modeling: Foundations and extensions. Thousand Oaks, CA: SAGE. 240 p.

Kuo, C. C.; Tsaur, C. C.; Chang, Y. Y. 2006. The study of norm for safety culture questionnaire in construction industry of Taiwan, Journal of Occupational Safety and Health 15(4): 91-103 (in Chinese).

Lee, S.; Halpin, D. W. 2003. Predictive tool for estimating accident risk, Journal of Construction Engineering and Management 129(4): 431-436. http://dx.doi.org/10.1061/ (ASCE)0733-9364(2003)129:4(431)

Liao, C.-W.; Perng, Y.-H. 2008. Data mining for occupational injuries in the Taiwan construction industry, Safety Science 46(7): 1097-1102. http://dx.doi.org/10.1016/j.ssci.2007.04.007

Lipscomb, H. J.; Schoenfisch, A. L.; Shishlov, K. S. 2010. Nonfatal contact injuries among workers in the construction industry treated in U.S. emergency departments, 19982005, Journal of Safety Research 41(3): 191-195. http://dx.doi.org/10.1016/j.jsr.2010.03.004

McKim, R.; Hegazy, T.; Attalla, M. 2000. Project performance control in reconstruction projects, Journal of Construction Engineering and Management ASCE 126(2): 137-141. http://dx.doi.org/10.1061/(ASCE)0733-9364(2000)126: 2(137)

Meliá, J. L.; Mearns, K.; Silva, S. A.; Lima, M. L. 2008. Safety climate responses and the perceived risk of accidents in the construction industry, Safety Science 46(6): 949-958. http://dx.doi.org/10.1016/j.ssci.2007.11.004

Mohan, S.; Zech, W. C. 2005. Characteristics of worker accidents on NYSDOT construction projects, Journal of Safety Research 36(4): 353-360. http://dx.doi.org/10.1016/j.jsr.2005.06.012 
Navon, R.; Kolton, O. 2006. Model for automated of fall hazards in building construction, Journal of Construction Engineering and Management 132(7): 733-740. http://dx.doi.org/10.1061/(ASCE)0733-9364(2006)132: $7(733)$

Saurin, T. A.; Formoso, C. T.; Guimarães, L. B. M. 2004. Safety and production: an integrated planning and control model, Construction Management and Economics 22(2): 159-169. http://dx.doi.org/10.1080/0144619042000201367

Stevens, J. 2002. Applied multivariate statistics for the social science. $4^{\text {th }}$ ed. Lawrence Erlbaum, NJ: Mahwah. 699 p.

Smith, G. S.; Timmons, R. A.; Lombardi, D. A.; Mamidi, D. K.; Matz, S.; Courtney, T. K.; Perry, M. J. 2006. Workrelated ladder fall fractures: identification and diagnosis validation using narrative text, Accident Analysis \& Prevention 38(5): 973-980. http://dx.doi.org/10.1016/j.aap.2006.04.008

Tam, C. M.; Fung, I. W. H.; Yeung, T. C. L.; Tung, C. F. 2003. Relationship between construction safety signs and symbol recognition and characteristics of construction personal, Construction Management and Economics 21(7): $745-753$. http://dx.doi.org/10.1080/0144619032000056171

Tsai, M. T.; Chen, B. M.; Chuang, L. M.; Tsai, H. C. 2003. A study of the related factors that affect perceptions of workplace safety: a confirmatory model of management influence on workplace safety, Journal of Human Resource Management 3(3): 127-152 (in Chinese).

Thevendran, V.; Mawdesley, M. J. 2004. Perception of human risks in construction projects: an exploratory study,
International Journal of Project Management 22(2): 131137. http://dx.doi.org/10.1016/S0263-7863(03)00063-2

Törner, M.; Pousette, A. 2009. Safety in construction- a comprehensive description of the characteristics of high safety standards in construction work, from the combined perspective of supervisors and experienced workers, Journal of Safety Research 40(6): 399-409.

http://dx.doi.org/10.1016/j.jsr.2009.09.005

Wang, W.-C.; Liu, J.-J.; Chuo, S.-C. 2006. Simulation-based safety evaluation model integrated with network schedule, Automation in Construction 15(3): 341-354. http://dx.doi.org/10.1016/j.autcon.2005.06.015

Wantanakorn, D.; Mawdesley, M. J.; Askew, W. H. 1999. Management errors in construction, Engineering, Construction and Architectural Management 6(2): 112-120. http://dx.doi.org/10.1108/eb021104

Wu, T.-C.; Lin, C.-H.; Shiau, S.-Y. 2010. Predicting safety culture: the roles of employer, operations manager and safety professional, Journal of Safety Research 41(5): 423431. http://dx.doi.org/10.1016/j.jsr.2010.06.006

Yu, T. K. 2006. An empirical study of web- based learning adoption the behavioral and cognitive styles, Journal of Education and Psychology 29(4): 687-717 (in Chinese).

Zohar, D. 2000. A group-level model of safety climate: testing the effect of group climate on micro-accidents in manufacturing jobs, Journal of Applied Psychology 85(4): 587596. http://dx.doi.org/10.1037//0021-9010.85.4.587

Zou, Z. L. 2008. Solving safety problems associated with construction projects in Taiwan, Journal of Chinese Institute of Civil and Hydraulic Engineering 35(2): 58-64 (in Chinese).

Wei Tong CHEN. Professor and Chairman in the Department of Construction Engineering at National Yunlin University of Science \& Technology, Yunlin, Taiwan. His major research interests include construction safety, scheduling and planning, project performance evaluation, and value management.

Chun Sheng LU. PhD in the Graduate School of Engineering Science \& Technology at National Yunlin University of Science \& Technology, Yunlin, Taiwan. His main research interests include construction safety and public projects management. Mr. Lu was the division chief of Public Works Department, Chia-yi City Government, Taiwan.

Shu-Shun LIU. Associate Professor in the Department of Construction Engineering at National Yunlin University of Science \& Technology, Yunlin, Taiwan. His major research interests include construction optimization applications, project scheduling, and construction E-business.

Min-Shun WANG. Associate Professor in the Department of Banking and Finance at Kainan University, Taoyuan, Taiwan. He is an activate Architect in Taiwan as well. His major research interests include property management, disaster prevention and construction management. 